IN PUBLIC SCHOOLS,

$$
B S
$$

EDWIN F. SMALL.

SACO, MAINE:

PRESS OF THE BIDDEFORD JOURNAL. 1884. 


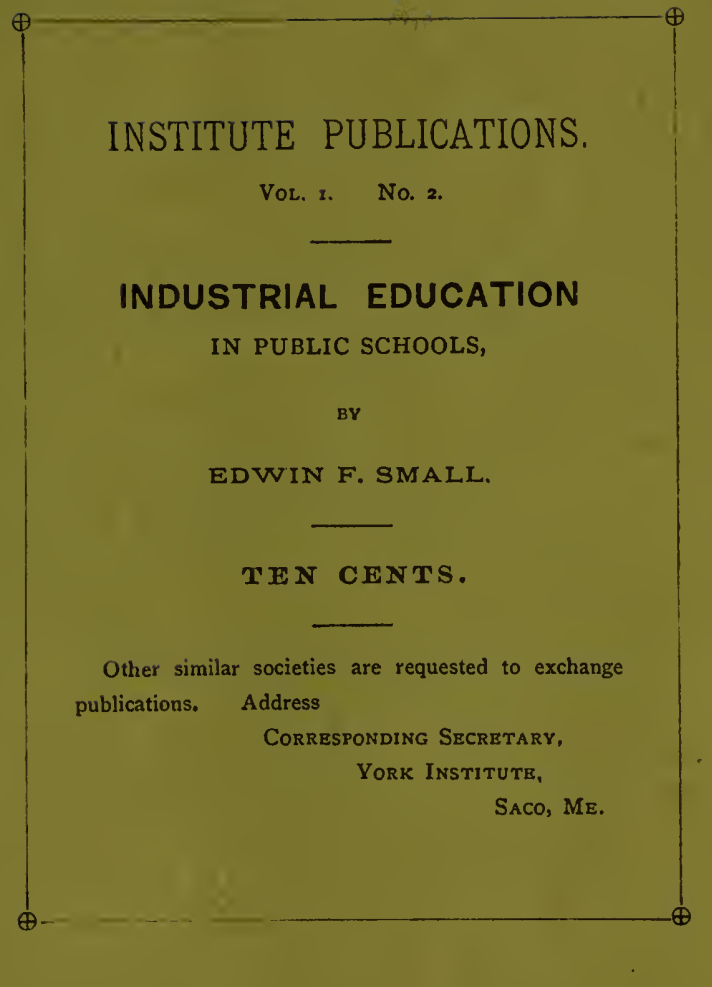


Yispe inativete, Socr, ine.

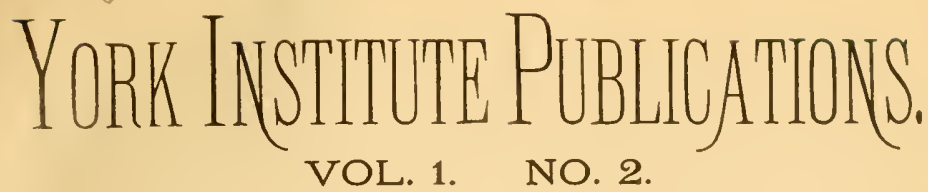

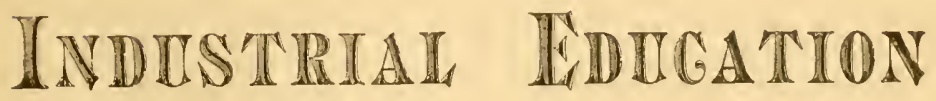

\section{IN PUBLIC SCHOOLS,}

$$
\text { BY }
$$

EDWIN F. SMALL.

SACO, MAINE:

PRESS OF THE BIDDEFORD JOURNAL. 1884. 
F. 7

. Y 697 


\section{Industrial Education in Public Schools.}

Address delivered Feb. 13, 1884, before the Society.

\section{Ladies and Gentlemen :-}

In selecting the above subject on which to prepare a paper for the York Institute I feel there is no necessity for making auy apology, as the purpose and aims of this Society embrace, among other things, all schemes for the promotion of educational interests. The present aspect of public school education is attracting more and more the attention of all classes, both in this country and in Europe, and great improvements have either been adopted or suggested for greater efficieucy in our school system within the past few years.

It has been said by some educators, only recently, that the public school instruction is for the few rather than for the many, and that its methods are designed more for the well-to-do classes than for the poor. The general impression has got abroad that the instruction commonly given in our high schools fits a youth for a clerk-ship in a store rather than for the technical work of a trade.

However that may be, an effort has been made by influential persons in some of our larger cities to supplement the ordinary instruction given in the common schools by a certain amount of mental and physical training in the different branches of industry.

One very successful enterprise has been started in Boston by benevolent and philanthropic ladies, which has for its main object the furnishing free of cost to all poor girls 
practical instruction in the various duties of household work. On one or two afternoons of each week these children are gathered together in a room properly fitted up with all the necessary requirements, and under a competent and skilled instructress are taught to make, open and air a bed, to sweep and dust a room, to set a table, wash the dishes, cook, and iron, and whatever else is required to make a model servant or housekeeper.

The advantages, both moral and material, to the poorer classes from this teaching are incalculable, and the result of a few years of such work has well justified the charity which prompted the effort.

A movement is now on foot in the city of Boston to introduce this species of industrial training into such of the public schools as are necessary to give the plan a fair trial, and to see what results will accrue from it. Again, in several of our leading cities, a system of technical and scientific instruction, combining theoretical with practical training has been successfully established, with the design of preparing young men from sixteen to twenty years of age for the duties of an active life, "which is broader and brighter than the popular method of learning a trade, and more simple and direct than the so-called liberal education." "It is the well-considered opinion of all who have had intimate knowledge of the working of this system that the connection of academic culture and the practical application of science is advantageous to both, in a school where these objects are started together and carried on with harmony and equal prominence." "The Academy inspires its intelligence into the work of the shop, and the shop, with eyes open to the improvements of productive industries, prevents the monastic dreams and shortness of vision that sometimes paralyze the profound learning of a college." One such school has lately been established in St. Louis, in connection with Washington 
University, but has a diflerent course of study and a different building. Boys can enter at fifteen and stay three years, when they are fitted to earn their own living in several trades. The first year they work two hours a day in the carpenter's shop, with instructions given by a college graduate, and a practical carpenter. The second year ther work the sume length of time in the blacksinith shop, and the third year in the machine shop. The course of study keeps along with their work, and also the drawing. So that the boys can make what they can draw and draw what they have studied about.

Leaving for a moment the matter of a higher technical training in the practical arts and scierces, let us look at the needs more particularly of our own eommunity, and at the advantages to be derived from a public school instruction in the ordinary branches of human industry.

It is a Prussian pedagogical maxim that "whatever you would have appear in the nation's life you must put into the public schools," and it is just as true of the smaller life of a town or village.

What is the object of education? Not merely the amount of knowledge that can be crammed into the mind for four, six or eight years of boyhood or girlhood, but the proper and harmonious developement of mind and body by such teaching as will draw out the latent powers within. Every child, of course, should be taught the elementary branches of reading, writing, spelling, arithmetic, geography and grammar in the primary and intermediate schools of the land. But when the question comes, shall we continue this free system in the high schools and academies, adding the higher branches of learning, and perhaps a classical training, then we ought to pause and consider, whether such a course is for the best interests of the community at large or for the few who are able to enjoy and profit by. this advanced education. 
It is just at this point that $I$ think a new departure should take place and instead of the ordinary methods now in vogue there should be substituted a course of industrial training, fitting the youth for the duties of active life. Such a course would begin after leaving the grammar school, and only those admitted to it who showed such natural ability and proficiency as to make it desirable. The course itself should include the higher mathematics applicable to the mechanical arts, one or more of the modern languages, free hand drawing, draftıng, some physical science, and sufficient practical familiarity with a trade as will secure a fair livelihood to the graduates.

The need of some such free instruction will be obvious to any one who considers the great demand made to-day for skilled mechanies in all departments of manufacturing and industrial pursuits, as well as the lack of means among onr laboring classes for giving their boys the time required for an education. A large majority of boys whose parents are working people cannot afford the time involved in a high school course and the additional yeurs necessary to learn a trade. Therefore they are usually taken out of school at the end of the intermediate course and placed as apprentices in some shop, or set to work in a store or factory where they must earn their own living. The result is that unless they are naturally gifted they will never rise above a mediocre position in their calling, and never attuin a due rank in society, because of lack of early and sufficient edueation. They are unfitted for the position of foremen or superintendents, seldom become master workmen, and are deficient in that intelligence and culture which enables them to enjoy the society of cultivated persons, or the higher works of literature and art. If they could be taught the principles of some mechanical trade, like the machinist's or the carpenter's, with sufficient practice to make them good workmen, and be instructed in the theory 
as well, they would be enabled to enter upon their life's work with minds developed and hands skilled, and thereby earn a better living and attain a higher place in the social world than they could otherwise possess.

There is no country in the world where the demand for skilled mechanies, or the compensation for skilled work is so great as in the United States. Our manuficturing interests are yet in their infancy, and with the almost unlimited natural resources of our fuvored country, there is uo prospect of any sudden lessening of this demand, but rather of its gradual and sure increase. The vast West is even now attracting daily large numbers of our active and able young men, and with her heds of coal and iron, gold, silver and copper threatens to compel the East to relinquish some of her prosperous industries. How then shall New England keep her lead in manufuctures, engineering and the incustrial arts? She must undoubtedly maintain schools of applied science, in which artisans, superintendents, agents and engineers may be thoroughly trained in the principles and practice of their trades and professions. Here in our own State, in which manufucturing and ship-building are the chief interests, we have three colleges providing what is called a liberal educution for ber sons while we have notbing worthy of the name of a University of Technology.*

The time has gone by when it is thought derogatory for a young man of education and ability to learn a mechanical trade, and already many of our college graduates are turning their attention to these pursuits in preference to the so-called liberal professions.

If the State wishes to develope her resonrees, increatse her manufactories, keep her sons from going. outside of her boundaries to seek their fortune, she must provide

\footnotetext{
*NotE. - This is not intended to reflect in the least on the excellent atricultural College at Oromo, supported by the State.
} 
them with the means of industrial education at horre, by establishing schools of the arts and sciences. An appropriation annully made from the State towards this end would, in my opinion, be money wisely expended. A central University, where both the theory and practice of agriculture, mechanical and civil engineering, and the physical sciences, together with a thorough course in literature and modern langnages could be the corriculum, would be a most importint step in the material welfare of the State, and me that would be appreciated and prized by the young men who ask for such trinining.

We have a need for better educited mechanics, not to. make them dissatisfied with their calling, but to stimulate them to greater efficiency and thoroughness in their respective trades.

A buy with a taste for mechanics, either natural or acquired, is forced to-day, by his slender resources, to begin work for his livelihood before his mind is developed, or his bands trained, and being thus checked in the commencement of life, will never be arrything better than a journeyman worker. Let the same boy go through a course of educational training, such as I have been describing, for three years before enteriug the workshop or factory, and in nine cases out of ten he will rise step by step to a position of honor and influence in his chosen career, while his moral and social surroundings will be commensurately higher. For, though I can only hint at these latter advantages, yet they are deserving of much consideration. What is the reason why so many of our ordinary mechanles are morally and socially, as well as physically on a lower plane than our college educated men? Is it not largely through lack of that culture and knowledge which a liberal education gives, and which teaches one the manners and usages of society, the self-respect and self-confidence which is unabashed in the presence of others, and 
the moral and healthful amenities which help to form a true gentleman? A trained and edneated mechanic will rather spend his evenings and holidays in edifying reading or in good social recreatious, than in frequenting barrooms or loafing in the street. He will want his home life pleasant and cheerful, will take due care of his own health and that of his children, will not treat his wife as a slave or servaut, and his children as brats, will seek for companions equal to himself, in fitct will be more of a man and less of a brute, by reason of that mental training which is his best preparation for life's duties.

"The relationship between ignorance and vice is patent to all men, but just where the connection lies is one of the most difficult of social problems. No man can be classed with the ignorant who knows any one branch of useful knowledge well and thoroughly. Science is tending to specialties, and art to technicalities. In all trades, business and professions, a man without some definite, practical knowledge, now-a-days, is to all intents aud purposes ignorant, unless his intelligence has been so cultivated that he is ready to learn whatever is current. The day of Jacks of all trades who are masters of none is gone by in the rush of human progress. Mechanics who have "picked np" their trades are set to tending machines. English lords and baronets are seriously betaking themselves to trades, arts and sciences, in sheer dread of finding their ocucpation of noblemen gone. As to the present common school system its grand error lies in assuming that all men have equal capacity, and in undertaking to do for the multitude what it is only possible to do for the few. It is an error which results in filling the heads of the young with a smattering of knowledge, which the philosophers call a bad thing, and with an enormous conceit which is much more dangerous." "Our cities are full of common school graduates who despise manual labor, and scramble 
by the bundreds for places behind the counter. It would be an interesting question to know how many of these ornamental and not useful graduates find their way to our prisons, reformatolies, and alms-houses." I have taken these last few paragraphs from a published article on ignorance and education, because they bear somewhat forcibly upon my present point. In answer to the inference which might be drawn from them, I think a public school training in one or more branches of industrial pursuits would mitigate the evil infuences implied.

It is no doubt necessary to the safety of a republic that its voters should have the rudiments of education, to be able to read, write, and think for themselves. Beyond these rudiments the masses of the people will not go. But for those who have the desire and ability to go further it is of the greatest importance that means should be provided by the State or Nation. What the nature of that later training should be is the question we are considering. For some the Cullege and University will always be attractive, and for them a proper preparation is necessary. But for others some kind of manual labor will be their chosen task. Why should not a course of preparation and training in our public schools be given, the results of which will more than repay the State for its expenditure?

As to the details of such a course experience and circumstances must decide. In many towns only one trade could perhaps be tiught. In other's a greater number, according to the means appropriated. The particular industries of any city or town would determine the question in that place, while іn others the demand would indicate what wonld be most necessary. In answer to the objection that industrial training would require additional teacher's and enlarged accomodations, as well as greater facilities for shop-practice than what our present system requires, I would say, wonld not the results be worth the 
cost? And even if at first it would be impossible to obtain shop-practice or the tools and machines reguired for experiments, could not the principles of a trade be taught, and ther working exhibited by models or by diarrams, and could not the problems of mathematies be so adapted to practical questions as to enable the pupil to get a pretty clear idea of what he will be required to do in after life? At any rate, certain time could easily be taken for instruction and practice in free-hand drawing, which would always be found useful in almost every trade.

But I think if proper attention were given to this matter hy the school horrds and educators many of these imagined difticulties would fade away. In a city like ours arrangements could probably be made with some machine shop or wood-room where a few boys conld have the opportunity to practice certain hours under a competent work-man in real manual work, until some better arrangements could he perfected. And if, as it seems probable in the near future, a suitable academy can be established here, which will mite with the present High School, then some such plan as I bave suggested in this paper might be earried out. 'The city would appropriate such sums as it could afford, and individuals in the town and county might be inclined to generously endow an academy or school of industrial education. The tendency is, I think, rather in this direction than in the line of mental training only.

I have in my mind a school of technology which has been successfully managed for fifteen yeat's, provided by the liberality of public-spirited and wealthy men, so as to furnish a theoretical and practical education free to qualiified boys in its own county in five branches of industrial art. These are mechanical and civil engincering, drawing, physies and chemistry. The course in mechanical engineering includes instruction in theoretical mechanics, 
applied mechanics, and practice. In theoretical mechanics the principles of statics and dynamics are taught and illustrated in the solution of a wide range of problems, and the same thing is done in applied mechanics relative to the strength, capacity and energy of various kinds of machinery. The practice is secured in a well-fitted machine shop, equipped with the best tools and machinery for the working of wood and iron, which is managed by a superintendent who employs a sufficient number of skilled workmen.

"The capital fact which underlies any sound scheme for school shops is that machinery is to have a constantly increasing share in the conversion of matter into useful forms. The educated mechanic must understand the practical limits of mechauical production and all the possible ways in which these limits can be extended. He must know by practice how to design, construct and assemble the parts of a machine, as well as how to finish its product by skillful handiwork. The power of the engineer to decide upon general principles the best form and material for a machine and to calculate its parts, is vastly increased by blending with it the skill of the craftsman in manipulating the material."

It is found by experience that the graduates of this school in the department of mechanical engineering are as skillful mechanics as ordinary apprentices who have served three years in a shop, and they have in addition the advantages of a solid education.

Now though snch an elaborate system cannot be expected in many of our towns as part of the public school instruction, I have thought it best to mention its general plan and outline in order to show what has been and is being done in the matter of industrial education. I am thoroughly convinced, from intimate knowledge and inquiry, that if a techuical school could be established in every 
eity of 20,000 inhabitants, and in every county where the gopulation was large enough and the necessities required, it would be of inealculable advantage to the young men aesiding in that locality and of great benefit to the community at large. It would be the means of developing the power and faculties of the youth, while it would alwakon a healthy rivalry and competition among the different manulacturing concerns who require skilled workmen. "There would be no need of sending abroud for trained engineers, designers or foremen. But we should be constantly supplying the demand from our home resources and at the same time offering to our young men facilities for a sound and thorough education which would largely increase their chances of success.

To recur a moment to a point already alluded to. Why should not equal prominence be given in our common school system to the principles and practice of a trade as is afforded for a classical and college preparation? There is not a high school in the land but what gives all who desire it the preparation necessary for a collegiate education, while there is not one, to my knowledge, that instruets boys or girls in any branch of mechanical industry. And yet the number who are obliged to work at a trade is very much greater than the number who enter college.

If the principle underlying our public school system is the preparing of youth for active work in all departments of human industry, then it stauds to reason that the eye and hand should be as well trained as the brain.

Every student in our high schools should receive daily instruction in free hand drawing for at least a part of their course so that discipline of the ideas of form and proportion may be secured, and the student when he undertakes shop-work may make more rapid and satisfactory progress than he could do if he had not had the advantage of this training. Aud again, the hours devoted to practice in the 
Trork-shop will serve the double purpose of teacting hab its of regularity and of furnishing a due amount of physical exercise.

In what has been already said it may seem to some that too much stress is laid upon one branch of industrial pursuits, viz: that of mechanical engineering. To this $I$ would answer by saying that the principles of mechimics. and the skill required in manipulating machinery enter largely into every department of manual labor. Whether a boy intends to be a machinist, or a carpenter, or a blacksmith, or a farmer, the knowledge of meehanics and their application to industry, as well ils the aptitude in handling tools will be indispensable requisites in the pursuit of their chosen calling. We shall never have the best specimens of farming till we have intelligent and well-trained firmers. A practieal and theoretical education in the principles of agriculture is as uecessary to-daby as in any profession or vocation. In understanding the nature and ingredients of soils, in the art of breeding the best stock, in the use of labor-saving machinery, in the due rotation of crops, and in the improvement of farm buildings an education based upon experience and practical training is imperatively demanded. And the same thing is true in every department of industry. The world is making great and rapid advancement in the cultivation of the arts and sciences, and whoever wishes to be abreast of the times must keep his eyes and ears open, and study diligently the best methods of performing a given work.

When we consider that the value of the railroad property in the United States alone is over $\$ 500,000,000$, or more than half as much as the value of all the farm property, and remember that this represents an immense body of skilled workmen in all trades and industries, we can see what a wide field is open for well-trained young men to get steady and remunerative employment. If our com- 
mron schools furnished free of cost the elements of mechanacs and a practice based thereupon, there is no question Gnt what their gr:nduates wonld quickly find congenial and well paid work throughout this great comntry.

A demand comes every year to all the technical schools of onr land for young men trained and edncated in some bratuch of industry to take charge of machine shops, to matnirge mines and factories, to act as superintendents or foremen, to anilyze metals and assay minerals, toplan and lay ont ralilroads, to be engineers on steam-ships and locomotives, in fict to occupy places of influence and usefulness in every branch of industrial work.

There is again a vast and increasing field of employment opering up on every side in the various applications sf electricity to the wants and necessities of life. To enter this field a course of training is reeded in the science of electro-chemistry and magnetism. A boy who is taught by practical experiment the principles of this great science with its complex workings, and with its various applications will never find himself out of employment, but be on it sure road to preferment and success. An objection is likely to be made by those who drubt the advantage of industrial training in the schools, viz: that it will inspire boys with a too lofty ambition and make them discontented with their lot in life. When they go out into active life and find themselves side by side with those not so well educated they will feel that they are fitted for something better than what their companions are doing, and therefore prove uneasy and dissatisfied workmen. In answer to this I would quote the old saw : "Water always seeks its level." Whatever a young man is fitted for he will some time attain. If his ideas are too grand a few weeks of rivalry and competition will bring them down. He will soon see that he that is faithful in little things will be most surely cntrusted with greater responsibilities. And even if his 
ambition is high, if there is the real ability in hïr, he will he a better workman by reason of it. There is always room at the top, it is said, and to seek the highest round of the ladder is commendiable in every case. But at course of industrial traning given in our public schools need not. be of such a character as will unfit a boy for manual labor by inspiring visionary ideas. Its effect ought to be to make him understand that a trade is as homorable as a profession if pursued honestly and industriously. The adrantage of an education is to improve his skill and train his natural powers to perform the best work.

And it must likewise be remembered that not every boy will be found capable of pursuing: such a course, that there will always be drones and idlers in the buman hive, and that for unskilled labor there is no immediate prospect of a lack of workmen. What we must aim to do is to select the best material out of the mass which is brought to as and endeavor to mould that into the proper shape and condition. The State is not responsible for natural incapacity or ingrained idleness in her citizens. Her duty is to provide the best and most varied preparation for the duties of life, and for the exercise of the right of eitizenship to all her children. After that each man and each woman must look out for themselves in the battle for existence. I am more and more convinced that the old Jewish principle of giving every boy a trade, whether he works at it or not, is the best principle for our day and generation.

How this shall be done, whether at public or private expense, is a question for statesmen and educators to decide. The fact that some of the most successful and sagacious manufacturers and business men, as well as many able educators continually recur to the idea of combining manual labor with school instruction shows the increasing attention paid to the subject, and is one of the signs of an approaching change in our system of public school instruction. 
In what has been said so far, I have spoken chiefly of a boy's education. The general principle will be found true in that of the other sex, with such changes in the details as are appropriate to physical and other conditions.

A large number of the girls of our land are forced to earn their own living. Let them be educated with a view to that object, even though many of them maly not be called upon to go outside of their own hones. I will not enter here upon the vexed question of woman's sphere. But I know no reason why industrial training in such branches as women can profitably undertake should not be a part of her school life. The manner of training girls in the kitchen garden system, as invented by a lady in New York and described in this paper, needs but to be once seen to convince any one of its practicability and value. Could such a system be introduced into our common schools we should soon behold better homes, more cheerfinl surroundings, a wiser economy in honsehold expenses, a he:llthier class of women, and a higher moral staudard among our poorer classes than is seen to-day. For what is needed to elevate both man and woman is a thorough, well balanced and harmonious education, which developes equally borly, soul and spirit; that will banish ignorance, vice and poverty to the limbo of the dark ages, and restore man to his God-like nobility of true manhood and wommhood.

Since writing the above my attention has been called to a proposed plan of annexing a Textile Laboratory and Museum to the Massachusetts Institute of Techuology, the chief features of which it may he interesting to notice here. The design of this new department is to give it thorough scientific instruetion combined with experinental practice in all matters relating to the treatment of the raw material used in the manufacture of textile fibrics. In the first place would come a study of physical geograt- 
phy, geology and natural history, and the chemistry of soils in relation to all vegetable fibres and to all animals which yield fibres to the textile arts. Next would come the physical study of the fibres themselves with the microscope, the polariscope, and the camera, and an eximination of all kinds of cotton, wool, flax, hemp and silk. Then the study of the manıficture of all textiles historically and mechanically. Next the fundamental principles of all the machines which are in use, with laboratory practice in the art of calding, spinning and weaving. The professor of architecture would be called upon to give lessons in mill construction. The professor of underwriting might be called in to aid with a special course, and might teach something more than the art of saving property from fire. And finally, the professor of political science would treat the condition of the operative, and the historic changes which the introduction of machinery has made in the condition of the people of all linds. In short, the professor of every science would be called upon to do his hest in the instruction of students in the textile department in order that they might be well qualified to take their degree and enter upon the work of life as well equipped as they should be. When it is considered that the annual value of the textile industries of the United States already amounts to more than six hundred million dollars, and that of the imported products to more than one hundred and twenty-five millions, can we not see what a wide field is opened for qualified young men to enter upon this one branch of buman industry. And yet in this conntry there is no school for special instruction and training in this department, while in Europe there are already many well established, and others still in prospect.

At Crefield, Prussia, there is a building which is to be wholly devoted to weaving and dyeing. At Bradford, England, there is a Technical school which is to be devot- 
ed exclusively to the art of manufacturing, dyeing and finishing what are known as "Bradford goods." At Batley, at Glisgow, at Leeds, at Huddersfield, and at Manchester there are alreacy fully equipped schools for technical instruction in particular arts.

Now if such a begimning as is here proposed becomes an actuality there will soon follow special trade schools in all our manuficturing centres. It will not be many years before Lowell, Lawrence and Manchester will have textile schoois. Holyoke will have its laboratory of paper making, Comnecticut will have its special schools in brass and other fine metal working. Iu this way and in this way only will New England be able to maintain her supremicy in competition with other parts of our common country which are more richly endowed by nature. "Is there any reason why the study of the art in which a man is to employ his working life, and by which he is to sustain himself and others, should not be made use of to develope bis own mind? Will he not take a greater interest in such a study and develope his own capacity more fully than he will in the study of something entirely foreign to this purpose? Is a study less fit as an intellectual exercise because it is useful in a material sense?" 


LIBRARY OF CONGRES

I IU|

0139953423

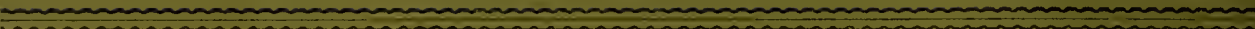

